Journal of Social Sciences (COES\&RJ-JSS)

ISSN (E): 2305-9249 ISSN (P): 2305-9494

Publisher: Centre of Excellence for Scientific \& Research Journalism, COES\&RJ LLC

Online Publication Date: $1^{\text {st }}$ January 2019

Online Issue: Volume 8, Number 1, January 2019

https://doi.org/10.25255/jss.2019.8.1.41.62

\title{
Reading Turkey's New Vision Based Real Policies through an Identity and their Presentation in Series as a Soft Power: A Study on the Series, Resurrection-Ertugrul
}

\author{
Türker Elitaş \\ ORCID:0000-0001-8018-1208 \\ Communication faculty, Manas University, Kyrgyzstan \\ turkerelitas@gmail.com \\ Serpil KIR \\ ORCiD:0000-0002-6653-6102 \\ Hatay Mustafa Kemal University,Communication faculty, Turkey \\ serpilkiir@gmail.com
}

\begin{abstract}
Abstrac:
The mass media fictionalizes social reality by rebuilding it within the framework of dominant norms and it presents this new reality to its target group in a way that it substitutes the truth. Especially the television, the most widely used technology among mass media is a communication technology which is preferred as the most effective means in transferring the new reality to the society, as it appeals to both visual and auditory senses. The television is also comprised of a highly organic technological set-up, equipped with mechanical and also social qualities in which identities are also recorded, represented, identified and modeled. In this technological mechanism, especially series, which are widely watched by Turkish society, are a privileged generator with regards to the reconstruction of identities. From this point of view, the purpose of this study is to demonstrate that Turkey, which tries to produce new and active domestic and foreign policies in global politics by taking advantage of the historical and cultural heritage, has started to use these policies as a soft power and TV series have been involved in this process. In this context, the series called Diriliş-Ertugrul has been studied as a sample and the indicators of the real policies based on Turkey's target vision have been evaluated by content analysis method. The findings put forward that besides providing historical information, Diriliş-Ertugrul transfers Turkey's new political identity pointing to its new vision based real policies and focusing on national unification inside and historical and cultural touches outside, to soft power elements over retrospective codes, and this is 'carried out' within narrative, character, decor fiction triangle.
\end{abstract}

\section{KeyWords:}

SoftPower, Television, Representation, Identity, Diriliş-Ertuğrul TvSeries

\section{Citation:}

Elitaş, Türker; KIR, Serpil (2019); Reading Turkey's New Vision Based Real Policies through an Identity and their Presentation in Series as a Soft Power: A Study on the Series, Resurrection-Ertugrul; Journal of Social Sciences (COES\&RJ-JSS), Vol.8, No.1, pp:41-62; https://doi.org/10.25255/jss.2019.8.1.41.62.

This work is licensed under a Creative Commons Attribution 4.0 International License. 


\section{INTRODUCTION}

Within the social context, the world is changing through many concepts and values in which communication technologies are also important pistons, and in this change, countries try to display return policies to their own resources, values, and legacies, and they try to internalize anything offered by technology within the time loop in which even 'moments' become important. Trying to integrate many new values and concepts that emerged after technology and industrial society with their own essence and power coming from the past, countries feel compelled to dominate each other with the new power elements emerging with this integration and to create policies accordingly (Altamony et al., 2012; Kateb et al., 2015). Especially the countries that have a strong historical background that can shape the global capital flow with their economic parameters that can be a model with their technology and that become prominent in the World public opinion with the power of the values and institutions they have created and that achieve their national goals through these powers win without guns. These powers and values policy, described as soft power in public diplomacy is a diplomacy operation which Turkey has been trying to use frequently in the last quarter.

The policy of winning without guns that are interpreted as soft power in public diplomacy started to be used by Turkey especially in foreign policy in line with the Historical-Cultural and religious heritage of the past and today's World policies and it considers it both as a regional power and a part of economic development. While most people consider this policy implemented by Turkey in the global arena as Neo-Ottomanism, the governing power that implements this policy has announced its thoughts on objectives of the policy to the whole World with the President RecepTayyip Erdogan: "Turkey again abolishes its neighborhood that has been overlooked for decades. It pursues a proactive foreign policy from the Balkans to the Middle East and the Caucasus. Turkey's 'zero, problem, unlimited trade' policy with countries on wide territories aims to create a non-dogmatic stability space for all of us. We travel to 61 countries without a visa. This is not a romantic neoOttomanism. This is a real policy based on a new vision of the global order (Milliyet.com).

The governing power that expresses on every platform the importance of proactive availability of soft power elements tried to be used by Turkey which does not go after a romantic Neo-Ottomanism in foreign policy, re-determined the limits of soft power applications in the literature, a concept unique to public diplomacy according to its own dynamics and started to use this new Post-Modern power and balance policy in domestic policies efficiently.

Trying to build a bridge between the internal and external political actions and postmodernism based on heritage, Turkey handles such concepts as unity, solidarity, brotherhood, partnership, etc. depending on conditions by bringing the past to the present. Within Turkey's new policies determined by the course of the world, the Ottoman identity has gone beyond being a nostalgic object heading for the last roundup or an outdated view, and it turned into a cultural heritage, contemporary fellowship base and perhaps most importantly to an government practice. In this regard, the political dynamic that is always followed over an identity in the world order also got a meaning in Turkey as well and mediated in patterning the Ottoman Identity over political codes in a 
contemporary way. In this process, one of the mass media used by the political power at most for the discourse of 'New Turkey' patterned through new policies both inside and outside is television. Because television is a highly functional tool for reinforcing, transforming, and eliminating an established envisagement, as well as substituting various new variations of reality and replacing the reality gaining a place in collective consciousness.

Television not only establishes the truth, but it also breaks it and gives it a new direction. In addition, mostly the only way to make political, economic or social fictions acceptable by people is a television screen. In the television world, it is enough to experience reality through screens. For this reason, a large number of people who have never seen the United States, who have not witnessed any of its indicators directly, are afraid of it and what is more, they have sympathy and admiration for it as well.

In addition to all its influential features, the television also ensures that identities are shaped under the control of a power. Because the formation of an identity within social relationship patterns is the result of centuries of cultural activities and interaction of many elements. In this process, it is impossible to say that a certain power affects the form of identities. Because within the cultural adventures of societies, every situation they experience touches the core of identities along with culture. However, television combines all the conditions necessary to create an identity under the control of a particular power. The recovery of conditions allows a typology of identity chosen by the efficient power to be designed regardless of external factors, within the framework of areas brought by that power. As a matter of fact, through this technical conditioning operation even the external factors, described as enemies take action in line with the concepts of power.

Developing policies against nationalism and ethnic identity problems of Turkey that struggles with many internal and external threats, the governing power explains this policy and the name of the followed path through vision-based real policies in the international arena. At the same time, it is tried to be conveyed through television that the unity and solidarity of a state which is dependent on the state and representative elements of state can only be provided with tolerance and justice through new real policies against nationalism and ethnic identity discourses.

In this context, within the study all episodes of Diriliş- Ertuğrul have been watched and the presentation of new vision-based policies in this series has been analyzed through the content analysis method based on the fact that television is the constituent element of the new reality and the most important transmission tool of the soft power, DirilişErtuğrul has been positioned at the center of the study due to millions of viewers both inside and outside of the country, its high narrative power and also due to the fact that the social dynamics it establishes are closely related to the concept of Soft Power. As a matter of fact, the series mediates in spreading vision-based new real policies as a soft power element with the high rates of rating achieved especially in the Balkans, Middle East, Central Asia, and Far East countries. 


\section{About New Vision-Based Real Policies}

Having an important geopolitical and geostrategic position, Turkey has blended the legacy left by the Ottoman Empire and the lessons learned from the collapse of the Empire and shaped its internal and external policy accordingly. Especially in the last period of the Ottoman Empire, the steps taken with the idea of Ottomanism such as Imperial Edict of Gülhane, Edict of Reform, an announcement of the Constitutional Monarchy, and upper identity seeking that was tried to be built over the concepts of equality and democracy determined position of Turkey that had been changing systematically after the Ottoman Empire in the World scene and determined its position against the developments in the World.

Nationalist movements that started with French Revolution and caused a collapse of empires also affected the Ottoman Empire which was a multinational empire deeply, and the Ottoman Empire having problems inside and outside began to seek solutions against these nationalist movements. Although the Ottoman Empire, which was in search of an upper identity such as Ottoman Citizenship against the riots broke out with nationalist movements, tried to overcome the problem by granting the societies claiming independency new rights, this struggle was not adopted by people who were getting support from outside. Because Ottomanism was just a transparent identity to prevent independence movements, rather than being real steps taken for unity and solidarity of non-muslims. (Hanioğlu, 1985: 1389) In this context, Ottomanism is defined as " $a$ political and thinking movement positioned by the Ottoman Empire, that was planning to get rid of the independence movements emerged after the French Revolution with a new identity." (Hanioğlu, 1985: 1389).

The nationalist movements which had an impact on non-Muslims living in the Balkans within the borders of the Ottoman Empire were spread by the nationalist propaganda of the Westerners and this process led the Ottoman Empire to declare the Imperial Edict of Gülhane first and then the Edict of Reform. The main purpose of the Ottoman Empire, which tried to create a reflex against nationalist movements with Reforms, was to provide Ottoman patriotism. For this purpose, this decree prepared by Mustafa Reşid Pasha created fundamental changes in all institutions of the state and in the management approach. Non-Muslims were also granted the same rights and obligations as Muslims. However, this decree, which was not adopted especially by non-Muslims, was criticized by the Muslims as a result of the process conducted to have equal rights, and until the 19th century, the Ottoman Empire, which was the trustee of the Islamic world and the symbol of unity, began to move away from unity and solidarity (Demir, 2011: 331).

The Tanzimat Reform Era, a reference to an Ottomanism-based process, was a kind of change and transformation project. This period, in which social problems were tried to be overcome by Ottomanism, as it had always been in every field is also accepted as a period of transition from religious community to the nation (Demir, 2011: 331). The Ottomanism envisaged that nations living in the lands ruled by the sultan would benefit from all rights equally regardless of religion and race. The Ottoman Empire, trying to 
provide this with the Imperial edict of Gulhane, put the consciousness of being a nation in the center of the developments it conducted within this context.

The ideal of Ottomanism, which was attempted to be riveted by the Edict of Reform, was only sustained until the First World War. The internal revolts which started with the rebellions of the Greeks and the social reflections of the First World War after the revolts showed the Ottoman Empire that this ideal could no longer be sustained (Hanioğlu, 1985: 1393). The borders of new Turkey, established on the basis of a national identity following the proclamation of the republic became definite and it started to be found on democracy with different ethnic communities, even to a lesser extent than the Ottoman Empire. In this new Turkey found by ignoring National Pact boundaries, The Ottoman policy was also ignored and different political thinking was sought both inside and outside.

In the post-Republican period, when foreign policy led domestic policy, the establishment of foreign policy on getting along with the European States and the West led to the necessity of making many revolutions in domestic policy, and many leaders were eliminated and many riots were quashed during the process of making society adopt these revolutions. Evaluating that period, Türköne stated that in order for Republic to take root under the conditions of those days of Turkey and to be adopted, the Ottoman Empire needed to be rejected and a new identity needed to be created and therefore it was necessary to break down at all or to minimize the similarities with the Ottoman Empire. (1994: 8).

Turkey, which struggled to pick an exhausted nation up in its early years and which got organized around a leader had to remain distant from the Islamic countries, Middle East and the Balkans which were no longer within its geographical borders, when trying to design its internal policy, and as a result of this it was helpless against invasion of these geographies by colonist Western States. Trying to establish its foreign policy, Turkey left the Turkish World alone and caused USSR to become effective within the Turkish World (Yağbasan and Günek, 2010: 120). In short, Turkey tried to be by Europe and global institutions in early years of Republic in a defensive reflex in the foreign policy and this policy was reflected in domestic policy and kept Turkey away from the Middle East, the Balkans and the Islamic world.

Having tried to be by Western Countries and displayed a closed attitude to other formations throughout its Republic History, Turkey which could not have any moral heritage was isolated as a result of its neutrality policy in the Second World War. This loneliness led Turkey with geostrategic and geopolitical importance to change its foreign policy, and in the foreign policy, the objective was to establish relations with the Arab world. However, The USA's struggles to maintain good relations with Turkey for many reasons unlike Europe and U.S.S.R' s menacing approach in the region forced Turkey for a pro-American policy.

Turkey, which could not take independent decisions to determine its own policy in foreign Policy wounded Arab countries deeply as it became the first Muslim country to 
recognize Israel in 1949, and it voted for the Algerian problem to be moved into the agenda of the United Nations from 1954, and the good relations that were tried to be established were interpreted differently (Yağbasan and Günek, 2010: 121-122).

The problems with the Arab countries also continued in the post-war period; however, at end of the cold war, Turkey increased its value in the eyes of the Western Countries due to its history and location. Having tried to reflect these opportunities and threats against Western Countries into its foreign policy, Turkey developed an active and multi-faceted understanding within domestic and foreign policy; in this context dependency on the Western Countries and NATO turned from one dimension to bilateral and multidimensionality (Duran, 2008: 387).

Making plans to turn the opportunities and threats that emerged after the Cold War into advantages, Turkey took new steps within foreign policy especially with TurgutÖzal, considering the fact foreign policy is closely related to domestic policy. These steps started to be discussed over and besides being a regional proactive player in the Middle East, they were also based on a policy which required integrating with Western Countries but not moving away from the Balkans and Turkish World. Özal, who wanted to develop the relations with the Turkish States that emerged as a result of the disintegration of the USSR, tried to ensure the unity and solidarity of the Turkish World with this process.

Turkey, having undergone a structural transformation with TurgutÖzal is described from the eye of Murinson as follows. "... He argues that the Kemalist Leadership worked for 70 years since the foundation of the republic to provide the state with Western and secular character, Kemalism's strict nationalist and secularist dogmas got institutionalized within the dominant and bureaucratic-authoritarian structure of the state, the first person to try to break down this was Özal"' (Cavlan, 2010: 130).

After the death of Mustafa Kemal Atatürk, the Turkish politics, which had a policy of turning its eyes to non-European geographies, developed a different discourse with TurgutOzal. Özal, who stated in his discourse of "Turkish World from Adriatic to Great Wall of China" (Efegil, 2008: 166-167) stated both his target and his desired limits of the Turkish world and he took on the leadership of a new target which was a mixture of Ottomanism and nationalism. While Turkey's new political discourse and ideas disturbed some people, some other people considered this political discourse as an incarnation of the Neo-Ottomanism within the policy.

Neo-Ottomanism. This concept is defined in different ways according to the political stance and the worldview of the explanatory. Nationalist conservatives handle NeoOttomanism by blending it with nationalism and Islamism and they approach NeoOttomanism more positively than those who position themselves as republican and who assign a negative meaning which is Middle Easternization to this concept. In the light of the fact that it is difficult to make a clear sense because of being caught in the middle, it will be appropriate to state that the Neo-Ottomanism debates were brought to agenda with TurgutÖzal. 
Davutoglu, who makes foreign policy assumptions and implications over the Strategic Depth Doctrine, refers to efficient and strong periods of the Ottoman Empire by stating that the Turkish foreign policy will not be built on a policy that is based on passive, humble, wait and see understanding; but instead it will be built on the characteristics of being effective, intervening and leading. (Davutoglu, 2009). While some people who associate Davutoglu's foreign policy statements over the Strategic Depth Doctrine to Özal's foreign policy discourse put the Neo-Ottomanism movement again into words, Davutoğlu has emphasized several times that this understanding is not Neo-Ottomanism and that people cannot do politics either in domestic or foreign policy with such an understanding. Stating that Turkey needs to be under a single roof with all ethnic elements in domestic politics, Davutoğlu considers all kinds of ethnic and cultural elements as builders of upper identity, on the other hand he states that we should not turn our back to the cultural and historical factors coming from the Ottoman heritage (Davutoğlu, 2009).

Turkish Republic's President, RecepTayyipErdoğan, calls Turkey's stance in domestic and foreign politics 'vision based real policies', and he put an end to new trends of each period and name seeking. He states that in today's conditions, politics becomes effective with vision and applicable policies rather than ideologies. In this context, as of today, domestic and foreign policy actions of the governing power, which have been constantly discussed throughout the Turkish political history, will be discussed through actions, not through ideology.

Turkey already has potential powers in terms of physical, geopolitical and many other features. What is important is how the governing power will use this potential power. Today, Turkey's governing power is trying to use this potential through a vision based real policies. In this context, it will be possible to list the main characteristics and objectives of vision based real policies as follows.

1. Turkey's geography is of vital importance within world geography. Therefore, it must establish close relations with both the West and the East.

2. It is obligatory to highlight policy-making over the historical patterns in building national identity, especially in domestic policy, which started first in Turkish political history with TurgutÖzal and which again came to the fore.

3. The purpose of the vision-based real policy is to integrate into Europe, which is restructured after the Cold War, and it also aims to neutralize the rising nationalist movements and to form a new political identity and culture.

4. As a matter of the cyclical structure of the world, taking actions with neighbors should be among Turkey's action plans for the foreign policy.

5. It needs to be able to use components such as model partnership, soft power, multi-dimensional politics, an alliance of civilizations, rhythmic diplomacy and shuttle diplomacy in place and on time, in order to use the vision-based real policies actively and effectively.

6. Linking Europe and Asia, developing economic relations with Russia and at the same time being an alternative route to Russia in the transmission of oil and gas to 
Europe, and improving commercial relations with neighbors constitute the economic dimension of the vision-based real policies.

7. The only force to ensure interaction between the Islamic world and Europe is Turkey. In this context, it is important to be a pioneer in achieving this interaction by benefiting from the Ottoman heritage.

8. It is obligatory to get organized inside and outside and to use all power elements in order to achieve all these targets.

9. The democracy revealed by Turkey after the proclamation of the Republic should be Pioneer to all other Muslim countries with its independent policies in all areas.

\section{Soft Power Resources and Strategies of Turkey}

The concept of soft power, which is frequently used in foreign policy and public diplomacy, is the situation where the actor (country) reaches the other actors who admire his values, who follows and models him in order to achieve his targets, and where he encourages other actors (Nye, 2005: 14). The soft power concept proposed by Joseph Nye for the first time in 1990 is the persuasion strategy, the exact opposite of the brute force.

Soft power-based persuasion strategies are a multi-faceted phenomenon in the context of politics and diplomacy, and they feed on institutions, values, technology, historical heritage, media, culture and politics as a resource. However, the most important thing for Nye, who defines soft power over the strategies implemented by countries in world politics, is that the power and objectives of a country should be accepted and legitimized by other countries.

In today's world, many countries use different resources of soft power. Undoubtedly, America, Japan, and Europe are more effective in the use of this power than other countries with strong resources. For example, Japan, which uses its technology and economy as a resource of soft power, has entered the most remote corners of all countries with its technology and has moved its culture to these countries. In addition, with this soft power resource, Japan is destroying the negative image it has drawn during the Second World War and threatening other countries with its technology in today's conditions. In other words, for Japan, technology as a soft power resource is a means of gaining sympathy and a means of giving the message of 'power'to other countries.

For security reasons, States generally use their military power or economic sanctions against dangers. This power implementation offers simple and short-term solutions. However, the use of soft power is a difficult process that requires extending over time and its effect is slow, widespread and heavy (Cavuş, 2012: 26). In this context, America, which uses soft power in a multidimensional way with different sources, applies different strategies with its technology and especially with media tools. The most important one of these strategies is to make news about the image of the country which it sees as a threat for itself and to manage perception especially through media and to draw an American profile that assumes the protection of the whole world with the developed cinema sector. 
Many European countries, which have a common operational capability in the use of soft power, use this power through the values they create. The best example of this is the 'come and gone' relationship between Turkey and Europe during the European Union Process. Trying to impose the values they create upon Turkey, Europe is in an endeavor to present the World public opinion the image that they have the most important values of the World, and they use it as a soft power to many countries, especially to Turkey. Geun Lee who indicates that each country and unions have their own soft power strategies categorizes the soft power strategies implemented by countries and unions as follows.

1. To create or manipulate their own images to expand their security environments: Lee gives Germany's and Japan's strategy following the Second World War as a typical example of this situation. These two countries, which project a negative image after the war went into the effort of projecting a peaceful image.

2. To distort other countries' image in order to get support: Particularly America uses this strategy very often and smartly. Tarnishing other countries' image with the power of the communication technologies and the cinema sector, America has marked the Soviet Union as 'Evilness Empire' and marked Iran, Iraq and South Korea as 'Evil Axis.

3. Network effect strategy: The center of this strategy consists of certain extensive standards, codes of conduct and common norms. The purpose of the countries using this strategy is to change the norms, rules, and standards of the countries from which they get support. In short, to create global standards. For example, English became an international language with Washington Consensus.

4. To Accelerate Situational Conditions: This strategy is only used when a country intends to progress through an unstable change or crisis. Countries that have a respectable stance in the world public opinion often use this strategy as a soft power on relatively weak countries and they feed on increasing tension.

5. To use heroes and celebrities: Heroes and celebrities can be used as a soft power strategy in two ways. The first one is shown as a role model to other countries by being produced as a source of pride in their own countries. The second one is to use them in international agenda as well to achieve national or international goals (Lee, 2009: 214-215).

Each country has its own soft power resources. However, many countries either have not been aware of their soft power potentials or could not find a comfortable basis where they can use them in foreign policy. Turkey is the best example of this situation. Turkey closed itself to geographies where it can use its soft power in the easiest way due to its foreign policy line it followed until the 2000s and it particularly followed an America and Western Axis based policy, and in this process, America, Europe, and other structures have never allowed Turkey to use its soft power.

Having embarked on different quests in foreign policy after the Cold War period, Turkey endeavored to improve relations with geographies to which it had closed itself by then, and in this process it used historical and cultural heritage from the Ottoman Empire, geopolitical position, a strong army, democratic governance and a secular Muslim image as soft power resources. 
Turkey tried to implement the policy, it had adopted in domestic and foreign policy after the cold-war period by using its soft power elements. This effort, which started with TurgutÖzal, was attempted to continue by governing powers in a way, even though it was deferred, and accordingly, the attempts to surpass different ethnic identities and different nationalist discourses were tried to be eliminated completely; unity and solidarity were emphasized frequently, an integrative identity was tried to be formed and this was realized through an understanding that was seen as a constituent element of national identity. The peace and friendship-oriented foreign policy was strengthened with the discourse of Islam in the Middle East, with Turkishness in Turkey republics, and Ottoman heritage in the Balkans and in Africa and the soft-power strategy to be applied by Turkey in foreign policy has been tried to be built through these discourses.

Having changed the policy implemented on the Middle East in the post-cold war era and having started to handle Muslim World's problems, Turkey began to apply this policy more efficiently with Justice and Development Party and sought to develop its relations with the Middle East in the religious fellowship axis. Trying to be a mediator country to find solutions in the Middle East with its religion-focused policy, Turkey has been a role model in the Islamic World with its secular and democratic values as well. While all these developments have provided a basis for Turkey to display its soft power in the Middle East policy first and then in the Islamic world, Turkey has been accepted as a bridge between West and the Middle East in the presence of Western Countries as well with its Muslim identity and its adoption of democratic values and it has had the opportunity to use soft power against the West with this feature. In this context, the value of democracy in Turkey has been a source of soft power both in the Middle East and in the west.

Turkey is seen as a bridge between the West and the Middle East in terms of just values. Turkey's geopolitical position connects the West and the Middle East physically. Similarly, having a position to connect Asia and Europe, Turkey has the opportunity to use its geopolitical position as a soft power. Turkey has never lost interest in the West, and it has tended to protect its borders with the West and joined the NATO. Continuing its existence in NATO with a strong army, Turkey has the world's second-biggest army and it draws a profile to be feared with support given by NATO. Despite its strong army, Turkey has not been a warrior and it has used this military power as a soft power source.

Trying to balance its relationships in the Caucasus, the Balkans, and Africa sensitively, Turkey refers to the past frequently in this context. Building its soft power through its history and sense of culture, Turkey has tried to build good relationships on this geography especially after the cold war and in this context, it used Ottomans' heritage as a resource of soft power.

"...The Ottoman Empire ruled over three continents, which are Asia, Europe, and Africa. These two great states, our ancestors, predecessors, have never treated the countries in their region or Africa with racist, colonialist or enslaving mindset. We have always seen the peoples of Africa as our sympathizers and sidekicks. Although our languages, values, ethnic backgrounds and appearance are different, we feel that we have tarred with the 
same brush. We have always appreciated the ancient civilization of Africa. We have not been one of those who approaches Africa's sufferings politically, strategically and manipulatively. We have always approached mercifully and conscientiously. In the same way, we have always considered happiness and achievements of Africa as our own happiness and achievement." (Tccb.gov.tr).

Being aware of its soft power resources, Turkey has tried to use its soft power inside and outside through different strategies. Especially with Justice and Development Party, Turkey is trying to use this potential even more actively. While trying to organize its internal politics in line with national identity, Turkey is in a tendency to have zero problems with neighbors and to have more friends in foreign policy. In this context, under the roof of democracy, it frequently emphasizes Turkism in Turkish Republics, Islam in the Middle East, Ottoman's Heritage in the Balkans and Africa and differences, tolerance and mutual relations in Europe.

Containing all these values within itself, Turkey has been trying to exist in various geographies with various government agencies, it has built mosques in Islamic countries, brought in Ottoman antiquities to the present day in Africa and the Balkans, together with such institutions as YunusEmre Institutions and TIKA it put many projects in effect in the Balkans, Africa, especially in Turkey which present Turkey. Similarly, trying to get benefit from the power of the mass media, Turkey also began to market Turkish series to the Middle East, the Balkans and the Republics of Turkey, and used mass media as a soft power resource and strategy.

\section{Turkish Series in parallel with Soft Power and Television Relation}

One of the most important projections of soft power is undoubtedly the media. Especially the fact that the cold war ended and countries focused on their own development have brought different domestic and foreign policy tendencies. In this context, the media has become one of the most effective methods used by governing powers as integrative in domestic policy and as a moderator and builder in foreign policy within the change and development process of countries.

Each country shapes its foreign policy with the idea of being a model for other countries and turning it into social and economic benefits. For this reason, the media is a very important power. Turkey shows this power through television series. The series and cinema sector which has been making progress in recent years in Turkey is one of the most important capital that has been imported.

According to OECD reports, people watch TV for 3.9 hours on an average. This average increases especially in the evenings. There is no doubt that the most important factor in watching TV for hours in the evening is a soap opera kind of series. The most popular topics in the television series, where almost all kinds of topics are handled, are the mafia, love and the series fictionalized over identities. The TV series fictionalized over identities contain messages about domestic politics in particular. While these messages emphasize the concepts that include such national elements as unity, solidarity, and brotherhood, they build a perception in society over these concepts. Soft power is a term used for 
foreign policy and public diplomacy. However, today's conditions compelled Turkey to use this element in its own country. Considering the cultural values inheriting from the Ottoman Empire as a soft power resource, Turkey offers the representatives of upper identity, which are a flag, homeland and national elements to people through series.

Television has a vital importance in terms of giving social perception and social message, and it achieves these goals through programs and especially through series. Desiring to spread its historical hinterland in foreign policy through series, Turkey aspires social and economic development and integration, while it aims to prevent cracks and to strengthen the social structure which is unique to Ottoman Empire within the domestic policy with the idea of New Turkey.

\section{METHOD AND TECHNIQUE Problematic of the Study}

The subject of the study to handle new Turkish identity which is patterned with a vision based on real policies through television. The new Turkish identity, formed through a vision based real policy covers elements and values of the Ottoman Empire, it also eliminates disagreements on identity such as ethnic identity, national identity, religious identity, etc., which exist in countries that have a mosaic social structure like Turkey, and it is also interpreted as an effort to create an upper identity. Debates on identity are being tried to be overcome with these new real policies in Turkey. This understanding envisages that everybody living in Turkey shall have equal rights, and everyone is organized around unity and solidarity. The most important tool used in this organization is television the most effective programs are television series.

Recently, it is possible to watch lots of series in Turkey that have been fictionalized over identity. These series have a unifying feature rather than being a separator. One of these series is Diriliş-Ertuğrul which is broadcast on TRT television channel. Even though TV series is based on social reality, it presents the reality in parallel with the perception it tries to create. Therefore, television series are an important indicator for both explaining social reality and understanding the social perception that is tried to be created. Therefore, this study has been prepared considering how new vision-based Turkish identity is presented in Turkish series.

\section{Purpose and Importance}

The purpose of the study is to examine television series that support the policies which change with each governing power in the light of the effort to find a name for Turkish policies that survive until today and to research their contribution to political courses. In this context, it has been determined that discourses of RecepTayyipErdoğan, Turkey's President, who puts an end to this kind of discussions, by saying 'vision based real policies are the name of a domestic and foreign policy of Turkey' are frequently supported in today's Turkish series. In this context, one of the objectives of the study is to analyze how vision based real policies are fictionalized and transmitted in television series in both domestic and foreign policy. Starting from this slogan, representatives, topic, storyline and new elements and values of Turkey's vision based real policies given in Diriliş-Ertuğrul which has been selected as a sample have been tried to be explained 
with various categorical analysis. The study is important in terms of analyzing reality and the perception that is tried to be created in television series from a different perspective. Another issue that makes the study important is that it is an academic resource in terms of the studies to be carried out with this regard.

\section{Target Population and Sample}

The target population of the study is the television series, which builds the storyline over the identity elements of Turkey. The sample of the study is the series called DirilişErtuğrul, which was selected by purposive sampling which is one of the improbable sampling types. There is no chance of equal selection for each of the sampling units in the improbable sample type. The researcher's personal opinions and transactions gain importance (Erdoğan, 2012: 208). This type of samplings requires the fact that the units should have a number of characteristic features rather than being chosen neutrally (Koçak, Arun; 2006: 25).

\section{Data Collection and Analysis Technique}

The conceptual framework of the study is composed of Turkey's vision based real policies, soft power concept that makes reference to the use of these policies inside and outside as a power and the television which is the most important tool of soft power.

In the research part of the study, a content analysis method was used to understand the existence, purpose, process of DirilişErtuğrul and the elements of the new vision based real policies. Content analysis, a qualitative research method, is a technique ensuring that the content of different types of texts is analyzed methodically, systematically, impartially and quantitatively, if possible in order to classify and interpret the original elements that cannot be understood with a naive reading (Bilgin, 2006: 2).

The data collected from the Diriliş-Ertuğrul, which was chosen as the sampling unit, was obtained by watching each episode in detail. The data obtained were analyzed by the categorical analysis technique which is one of the content analysis types. "Categorical analysis, in general terms, refers to the division of a given message into several units first and then examining these units as categories according to certain criteria. Categorization is the process of coding the messages: (Elitaş and Keskin, 2016: 561). In this context, the study is based on the series of Diriliş-Ertuğrul; the plot was categorized as characters, stage-decor-costumes, and the findings were evaluated over these categories.

\section{Indicators of New Vision Based Real Policies within the Plot}

Identities come into being as a result of social relations with organic environments and they gain meaning through these relations. For this reason, each identity is evaluated together with its typology specific context, in other words with its social World and it is interpreted considering the general structure of this world. The television series, which bring together different indicators and form a community construct, constitute a unique model of society through fictional relations. The plot in the series refers to a form of social relationship in itself. For this reason, the organic context, which is essentially needed by identities, is established by articulating elements of the community 
represented in the plot. The plot in the series, together with the reconstructed reality, determines structural qualities and category of identity.

The plot described in the series first begins with the name chosen for the series. The name Diriliş-Ertugrul gives clues about the topic of the series and which person will be the main character. There are two reasons for choosing this name if an evaluation is to be made in terms of the scope of the study. The first one is the expression of "Diriliş (Resurrection)" that is emphasized in the series. This expression, in the first sense, refers to a nation that gets rid of frustration against the surrounding conditions, while its second meaning refers to the Ottomanism identity. Because the emphasis is on" Resurrection" movement of Ottomanism identity, which began to be forgotten in the Republican period and which has been described as an outdated identity structure. In fact, this resurrection is a statement heralding the rebirth of Ottomanism. Note that, "Resurrection" has been used rather than "Rise" for the series. Because the concept of resurrection primarily requires "dying". In this case, the Ottomanism identity, which is "dead ", resurges with the series and it makes an appearance.

The other reason for choosing that name for the series is to take this identity back to the Pre-Ottoman period and to give it a very strong origin. Because the series narrative which focuses on the Ottoman Empire was scripted on Ertuğrul, father of Ottoman's Empire founder- Osman who gives its name to the Empire, rather than being a script on Osman himself. In fact, this explains the relationship between identities and origin. Because an identity is meaningful only in the context of belonging to a strong origin. The series brings the Ottoman Identity to the Pre-Ottoman Empire, to Central Asian Turks. In fact, it highlights the idea that it is an integral part of Turkishness and an identity that develops with Turkishness.

Taking a different approach to Turkish history and drawing the attention of Turkish people for its topic, DirilişErtuğrul is among the most-watched programs since 10 December 2014. Explaining the Ottoman Turks getting on history stage and the difficulties experienced throughout history, it has many actors and actresses and technological opportunities and a big budget are also provided for this series. Living a nomadic life under the leadership of Suleyman Shah, Kai tribe was involved in many battles with Mongol on one hand and Turkmens on the other hand, and at the same time, it had disagreements with Seljukians and suffered famine, drought, and diseases. Kai tribe, who had never fed up with this struggle with nature and other tribes, either laid down their life or fought or they migrated.

DirilişErtuğrul, which draws the attention of Turkish people from a different perspective and attracts the attention of the Turkish people, is among the most viewed programs since 10 December 2014. Explaining the history of the Ottoman Turks and the difficulties experienced throughout the history of a large number of players are used in this series and this wide range of players with technological opportunities and a great budget is accompanied. In the series in which the traces of nomadic life are seen in each episode, it is clearly shown to the viewers that today's borders were not easily formed and many wars were experienced for this reason. The theme of a fight for the homeland, which is a 
clearly used theme, and the metaphor of flowing blood for the motherland in this theme, draws the attention of the audience to national elements such as homeland and land.

The most important values of Kai tribe, who often migrate to establish a homeland, are horse and weapons. Kai tribe who gives utmost importance to their horses and weapons also give spiritual value to them. The best gifts to be given to one which is horse and weapon are an indicator of their warrior's identity and indicator and representative of the Turkmen identity. The Turkmen tribes, who obey the rules of Süleyman Shah, also shows that the leadership characteristic is an important factor for the survival of a tribe. In this sense, showing that a strong leader can turn a tribe into a country; but the weakness causes all kinds of dangers both inside and outside first through Suleyman Shah later through ErtugrulGazi, this series gives the audience a political message by showing evidence from the past.

The series, which shows that leadership is an important constituent element, also refers to democracy through established councils and co-decisions. In this context, the viewers are made to think that a tribe can become an empire only through a democratic existence in the decision-making process, and the existence of a strong leader in the implementation of decisions. In the series of Suleyman Shah and tribe leaders frequently say that dichotomy means a collapse of the tribe. This situation emphasizes the importance of the fact that ideas can be discussed; however, the decisions to be implemented should be adopted by all tribe leaders. Turkish society is given the message of unity and solidarity. Kai tribes who are the founders of the Ottoman State constitute the starting point of both Ottomanism and Turkish identity. One of the basic elements of these two identities is hospitality. In many episodes of the series, this value is transferred to the viewers.

The series also builds a confrontational plot within itself with contrasting concepts such as cruel and oppressed. Giving subliminal messages through these contrasting concepts, the series introduces cruel people as enemies and traitors within the tribe and introduces oppressed people as tolerant, desperate and weak people regardless of their ethnic identity and religious differences. Using many values such as hospitality for oppressed people, the series gives the message that different ethnicities and different religions can be kept together with these values.

The identity is trying to be updated with the heritage from the past in Turkey which endeavors to re-form pro-tolerance and pro-oppressed policy against the anti-refugee movements. In this context, the Turkish history, which is a soft power element, is presented in series that are soft powers as well. One of the most important of these series is Diriliş-Ertuğrul. While the plot in the series develops among the good, the wicked and the traitors, the good ones are the Turkmens, the wicked people are Templars and the church, and the traitors consist of other leaders in the tribe or The Selçuk Empire. The wicked people are evident, and measures are taken against them, but it is difficult to take measures against traitors, and these traitors spell trouble for the tribe. 
Throughout the series, viewers are made to feel that making no comprises on traditions has an important effect on founding such an Empire in the future. In the messages emphasizing that traditions are one of basic Dynamics of a state, unwritten rules are of vital importance. Traditions and customs of the messages given out as a highlight of the fundamental dynamics of a state have an important place in the unwritten rules. These unwritten rules, called moral laws, are emphasized to be an important concept for the Kai Tribe first and then Ottoman Empire, in the same way, they are the distributor of justice. The family is the cornerstone of society. It is seen that the family, which has an important place in Turkish culture, has also been heavily used in the series. The main features of a family are forgiving and being tolerant and men have the last say.

The messages given take its source from the past and they draw attention to the importance of such concepts as tolerance, justice, hospitality, respect for the customs and traditions and family which should also be present in today's Turkey. The flag on each tribe leader's head is used as a unifying element. All these values, symbols and battles constitute the perception that it has not been easy to reach today and that and a structure created with the members of the community connected to each other with unity and solidarity will not bow to internal and external threats. Religious symbols are also frequently used in the series. Religious values are used in two ways. The first one is a narrative which is away from the Muslim identity (the Hospitallers) and the other one is a narrative implying that a tribe who comply with the rules of God and the Koran does not collapse thanks to the unifying feature of religion. This unifying power, supported by images such as starting the tribe meetings with basmala, the participation of all tribe people to the funeral prayers of the Alps, this is also used for the Templars who are marginalized.

As a result, the series represents a new reading, which is a mixture of Muslim identity, Turkish identity, and other national and religious identities, and which approach all identities tolerantly and equally. The name of this reading in today's politics is a new vision based real policies. In this policy, it is aimed that Muslim and Turkish identities are a unifying and integrative phenomenon and that the elements other than these identities should also be approached with tolerance. In particular, the series clearly indicates that the guest is welcomed to the tent, the tent is shared with him and people don't need to have any identity to be a value of the tribe. What is important is the welfare of the state rather than identity.

\section{Supporting the Narrative with Characters}

The subject of the series is to give the facts over an identity formation for the future by giving evidence to the historical heritage. The presentation of this new identity is based on vision, and it refers to the real target policy in domestic and foreign politics as well. Like many countries which try to give messages about the sense of belonging especially through television series, Turkey also tries to benefit from this soft power strategy efficiently in today's circumstances and it asks people to protect the value of their identity. Therefore, the self-identity of all individuals belonging to that group is also shaped by this identity. The characters in the series are very important in this respect. Because each character is a role model and prototype that describes individual identities. 
In fact, each character displays performance to show the audience the applications of identity. In this context, the principle of accepting differences lies behind the only Turkey discourse, trying to be formed in the light of new vision based policies, and the vision of creating a single identity reveals itself immediately. However, although the acceptance of these differences is an important factor in vision-based politics understanding, everyone must exist individually on the basis of a certain responsibility. In this context, characters' identities show what kind of an individual identity the men, women, the youth, children, politicians, managers, soldiers, doctors, tradespeople who adopt this identity will have.

The series includes many actors and actresses. However, the fact that the subject is transferred over Kai tribe features the characters representing Kai tribe. Suleyman Shah: $\mathrm{He}$ is the leader of the Kai tribe. As in all Turkmens, he is a strong, fearless leader who gives value to independence and does not bow to anyone. His only purpose is to ensure that the Kai tribe survives and lives in unity and solidarity. Suleyman Shah does not bestow a privilege on anyone for this purpose and he is a response to the question of how a Muslim-Turk should be. Valuing his morals above anything, Suleyman Shah takes his decisions in line with the rights determined by morals. He is very fair and modest.

Hayme Ana: A character who represents Turkish woman in the series in the strongest way, Hayme Ana is the wife of Suleyman Shah. She is by Suleyman Shah in any case, and she is the representative of tradition, who maintains order in the absence of Süleyman Shah. Hayme Ana, advocating concepts such as justice and tolerance left by her husband, draws the profile of the traditional Ottoman woman with her strong woman image.

ErtuğrulGazi: One of the two sons of SüleymanŞah and Hayme Ana, Ertuğrul is the main character of the series. He is the starting point of the process of establishing the Ottoman Empire. He is respectful to his elders, fearless to his enemies. Ertuğrul, a good fighter, considers his friend's brother and welcomed anyone who needs help to his tent. Being a representative of hospitality, Ertuğrul is also a representative of heroism and the Muslim Turkish youth.

Ertuğrul is the most commonly used character in transferring subliminal messages. The Ertuğrul character has all characteristics of unity and solidarity, tolerance, compassion, justice and sacrifice, which constitute the basis of vision-based real policies.

Gundogdu: Suleyman Shah 's eldest son. Gündoğdu, a warrior Alp-like Ertuğrul, draws the opposite profile of Ertuğrul as a character. Greedy for power, Gündoğdu who likes his brother but who is also jealous of him and he objects to his ancestors and the tradition when required, he has limited tolerance to strangers. He always competes with Ertuğrul in the series. The winner of this race, like the war of good and evil, is the owner of good virtues, Ertuğrul.

Turgut Alp: He is an Alp trusted by Ertugrul, and he is always by him. Turgut Alp, who could not get married to his lover due to the fights for the future of the tribe is the symbol of patriotism and patience. Just like Süleyman Shah and Ertuğrul, he loves his hometown more than his lover. 
BamsıBeyrek: He is one of the Alps who is loyal to Ertuğrul. He is a representative of purity, strength, and loyalty in the series.

HalimeHatun: HalimeHatun, the Seljuk Sultan, will be the wife of Ertuggrul in the future. HalimeHatun, who always had to run off with his father and brother because of the fights for the throne, finally took shelter in Kai tribe. She starts to consider herself a member of Kai tribe with loyalty and merit due to the hospitality of the tribe. HalimeHatun, who is the representative of beauty, merit, and benevolence in the series, is presented as one of the sources of Ertuğrul's power.

All these characters and the values represented the function as a bridge between the past and the future of Turkey. The series focusing on the Selçuk Empire and Ottoman Empire reminds Turkey of the past, and it gives unity and solidarity messages. The series Ertuğrul, showing that many people with different ethnic values lived in unity and solidarity for hundreds of years, and the Ottoman Empire existed on many continents within unity and solidarity, tries to explain that this can also be done in today's conditions as well with both plot and characters.

\section{Strengthening the Narrative with Scene- Decor, and Costume}

The stage-decor-costume triangle constitutes the fictional founding elements of the social structure modeled by series. The society model to be formed in the series is put into reality with the stage-decor-costume used. In this context, the social conditions related to the identity are provided through the indicators of reality and a social cover is placed on the identity. At the same time, the identity is interpreted by the audience by paying regard to the relation of the identity with these elements and also the relations they have established with each other.

In television series, the narrative is strengthened through certain elements. The most important of these elements is the stage, and decor design and use of suitable costumes for characters Since Diriliş-Ertuğrul is also a historical series, the conditions of the period are presented to the audience only through stage and costume.

The main point in the series is the events experienced by Kai tribe. In this process, Kai tribe has both friends and enemies. Enemies usually consist of traitors within the tribe and the crusaders. In particular, crusaders are described with the costumes on which religious symbols are clearly seen, they live in dark, gloomy castles with many dungeons inside. The dungeons of these castles are often dark and narrow areas where Muslims are tortured. The outside of the castle is filled with knights who have difficulty in walking on the mud. The castle metaphor creates the perception that the Crusaders are scared of Turkmen tribes, and the muddy areas where the knights wander give a social message to the viewers.

In contrast to the Crusaders, Turkmen tribes live in flat and wide plains which are open to danger; they do not live in castles. This creates the perception of a Turkmen who is not afraid of anything. In contrast to the crusaders, the area where the kai tribe lives is just a 
plain piece of land, rather than a muddy ground. Men of Kai tribe, who live together with the animals, wear costumes in which they can move easily due to their warrior identity; but they are heavy as well, while the ladies of the Kai tribe wear chic costumes designed with traditional Ottoman motifs.

The most important decor in the series is the area where tent towns are available with special effects. In this area, tents arranged sequentially behind the tent of the tribe leader attract attention. While this creates the perception that a strong leader always has his people behind him, this sequence is a different presentation of respect for the leader in the Turkmen tribe who adopted a military discipline.

Both indoor and outdoor area shootings were used in the series. While outdoor shootings are mostly the scenes in which the people of the Kai tribe take place within the plot, indoor shootings are mostly the scenes where the traitors and the enemies take place and they make hidden bargains and torture in these scenes.

\section{CONCLUSION}

Identity is discussed and modeled on the basis of ethnic and social phenomena according to the level of use in light of the indicators of today's scientific facts. Many scientists who explain the identity through these two concepts are optimistic about the variability of social dynamics and the disappearance of the boundaries that McLuhan defines as the Global village, and the emergence of digital individuals, places, minds, etc. Stryker and Burke, who did not address the identity in such a narrow sense, tried to explain the identity, which was tried to be explained by ethnic and social phenomena, with a new identity reading, which he called multiple roles. As a result of this reading, he says that the phenomenon of identity which symbolizes a belonging to us is a feature that does not change with ethnic and social status and can change with multiple roles (2000: 284).

The fact that identity holds a changeable feature in itself reveals the fact that an individual responds to all kinds of external messages and assimilates them. In this context, mass media, which particularly is an important means of conveying messages, can affect identities. The television, which is especially used by the individual both visually and audibly, is an important tool for establishing a new identity, resetting an identity, or reinforcing the existing identity. In new reality fictionalized over the identity through television, the presentation of subliminal messages and the repetition of these messages are constantly internalized by the receiver. In this context, television series play an important role in fulfilling this mission. Diriliş-Ertugrul, which is the subject of the study, also takes on a design task from this perspective.

The series, Diriliş-Ertuğrul- depicts a Turkish tribe's struggle for existing on the stage of history due to Muslim and Ottomanism identity. Within the course of a continuous struggle, the principle of contracts is used, just as the television wants to build. There is also a design of perception that is created as 'us' and 'them' in the series where good and bad conflict is generally used. In the series where "us" is embraced and "them" is considered a traitor, bilateral identity is built. One of the struggles in the series is the struggle of the two identities that are created as us and them. The basic characteristics of the identity presented as us in this struggle are that it is deeply tied to the rituals and 
religious values that are formed as a result of traditions and experiences, gather around a strong leader, overcome all difficulties with unity and solidarity, and have a patriarchal family structure. This is actually a narrative of the history of Turkey. This narrative intends to give today's generation subliminal messages and the main purpose of this narrative is that this generation is under attack as in the past, and we can only overcome this attack only if we adhere to the characteristics of our identity. The series shows these values intensively with the plot, characters and the scene, decor and the costumes.

The founding element of the Ottoman Empire is the Turkish and Muslim identity. As a result of the reflection of tolerance and justice of Turks and Muslims to the Ottomans, the State held different ethnic identities together for centuries, and in its social structure Muslims, Jews, Christians, Turks, Greeks, and Bulgarians etc. lived together without any problem. From this point of view, the series reminds the Turkish society of its history and treats a new identity which is the updated version of the Ottoman identity. Because this new identity presented with a new vision based real policies as a soft power element targets people from different religious beliefs, ethnic origin, and culture such Turkey Turks and Ottomans.

The narratives in the series go beyond a narrative frame in a mere representation practice or within documentary mood. Because the series, on one hand, witnesses the past, and it fictionalizes Turkey's identity over its new vision based real policies together with morals, origin, culture (see Shannak and Obeidat, 2012), kindness, essentialness, and reality which are attractive characteristics. It also turns itself into a glorious, historic, national, multilayered soft power to have an effect on people. In this context, in the "us" and "others" conflict that is handled in the series, it is always "us" to win. This situation and the definition of "us" and "others" are a part of the soft power of the identity.

The series handles the understanding of unity and solidarity on the basis of the state concept. The Holiness of the state which is also clearly emphasized by such statements such "Make or Break", the deep respect is shown to the flag and the statesmen, also emphasize the sensitivity of the concept of state to the viewers. As a result, Turkey's new vision based real policies are built over integrative concepts such as statism inside and over historical and cultural heritage left by the Ottoman Empire outside. In this process, all the characters organized around the state are the servants and protector of the state. 


\section{Reading Turkey's New Vision Based Real Policies through an Identity .....}

\section{References}

Bilgin, N. (2006). Sosyal Bilimlerde İçerik Analizi. Ankara: Siyasal Kitapevi.

Cavlan T. (2010). Yeni Osmanlıcılık: Batıdan kopuş mu?. Sosyal Bilimler Dergisi, Cilt,3 Sayı,2 ,ss.126-156.

Çavuş, T. (2012). Dış PolitikadaYumuşak Güç Kavramı ve Türkiye'nin Yumuşak Güç Kullanımı, Kahramanmaraş Sütçü İmam Üniversitesi İktisadi ve İdari Bilimler Fakültesi Dergisi, Cilt: 2, Sayı: 2, ss. 23-37.

Davutoğlu, A. (2009). Stratejik Derinlik, İstanbul:Küre Yayınları.

Demir, Ş. (2011). TanzimatDönemindeBirDevletPolitikasıOlarakOsmanlıcılık. Türkiyat Araştırmaları Dergisi, Sayı:29, ss.331-348.

Duran, B. (2009). Türk Dış Politikası Ortadoğululaşıyor mu?. Editörler: İnat, K., Ataman, M. ve Duran, B.,Ortadoğu Yıllığı 2008, İstanbul:Küre Yayınları.

Efegil, E. (2008). Turkish Ak Party's Central AsiaAndCaucasusPolicies: CritiquesandSuggestions. Caucasian Rewiew of International Affairs, 2, 166-172.

Erdoğan, i. (2012). Pozitivist Metodoloji ve Sonrası. Ankara: Erk Yayınları.

Geun, L. (2009). A Theory of Soft Power and Korea's Soft Power Strategy. Korean Journal of Defense Analysis, 21(2), 205-218.

Hanioğlu, Ş. (1985c). "Osmanlıcılık”,Tanzimat'tan Cumhuriyet'e Türkiye Ansiklopedisi, Cilt:5, İstanbul: İletişim Yayınları.

Http://www.tccb.gov.tr/ozeldosyalar/turkiye-afrika/zirve/, Erişim Tarihi:15.11.2016.

Http://www.milliyet.com.tr/erdogan-dan-dis-politika-yorumu-neo-osmanlicilik-degilreel-politika-siyaset-1340373/ Erişim Tarihi:18.03.2018.

Kateb, M., Swies, R., Obeidat, B., \& Maqableh, M. (2015). An Investigation on the Critical Factors of Information System Implementation in Jordanian Information Technology Companies. European Journal of Business and Management, 7(36), 11-28.

Koçak, A., \& Arun, Ö. (2006). İçerik Analizi Çalışmalarında Örneklem Sorunu.Selçuk İletişim Dergisi, 4, 3, ss.21-28.

Nye, J. (2005). Dünya Siyasetinde Başarının Yolu Yumuşak Güç, Çev: Aydın,R., Ankara: Elips Yayınları. 
Journal of Social Sciences (COES\&RJ-JSS), 8(1), pp.41-62

Shannak, R., \& Obeidat, B. (2012). Culture and the Implementation Process of Strategic Decisions in Jordan. Journal of Management Research, 4(4), 257-281. https://doi.org/10.5296/jmr.v4i4.2160

Stryker,S., \& Burke P.J. (2000). The Past, Present, and Future of an Identity Theory. Social Psychology Quarterly, 63(4), 284-297.

Türköne, M. (1994). Modernleşme Laiklik ve Demokrasi, Ankara: Ark Yayınları.

Yağbasan, M., \& Günek, A. (2010). Arap Medyasında Türkiye'nin Değişen Siyasal Algısı, Global Media Journal, Sayı:1, ss.117-143. 